Article

\title{
EFFECT OF AIR POLLUTION FROM PEDESTRIAN TRAFFIC IN AN OPEN MARKET: A CASE STUDY OF BODIJA MARKET
}

\author{
Oluyemisi Joy Oladejo ${ }^{1}$, Timothy Oluseyi Odeyale ${ }^{2 *}$ and Adiamo Rukayat Bukola ${ }^{3}$ \\ 1,3 Affiliation 1: Department of Civil Engineering, Public Health and Environmental Engineering option \\ University of Ibadan, Ibadan Nigeria; ojoyoladejo@gmail.com \\ ${ }^{2}$ Affiliation 2: Department of Architecture, University of Ibadan, Ibadan Nigeria; dr.odeyale@gmail.com \\ * Correspondence: dr.odeyale@gmail.com; Tel.: +234-81-3601-6354 (T.O.O.)
}

\begin{abstract}
Market air quality is very important to the economic lives of the people which is rarely researched, however, market activities particularly pedestrian traffic releases particulates which is detrimental to the health of the users and stakeholders. Thermo scientific MIE pDR-1500 particulate was used to monitor the quality of air within the market for eight (8) weeks, air pollutant of concern is PM2.5. ten (10) sample points were located in the market which covers ten (10) sample points for pedestrian traffic to represent the entire market environment spectrum. The analysis of PM2.5 measured daily during dry and wet season shows a clear seasonal variation of this particular pollutant as elevated concentration was measured during the dry season than the wet season. The assessment of PM2.5 concentration shows exceedances of the standards stated by WHO and NAAQS during the dry season which ranges from $47.9 \mu \mathrm{g} / \mathrm{m} 3-231.88 \mu \mathrm{g} / \mathrm{m} 3$ in the morning and $65.17 \mu \mathrm{g} / \mathrm{m} 3-1806.33 \mu \mathrm{g} / \mathrm{m} 3$ in the afternoon. From the findings, pedestrian traffic contributes immensely to air pollution in an open market, with this elevated concentration, prolonged exposure is highly detrimental to health. This study creates awareness to the pedestrians in an open market about air pollution and informs policy changes.
\end{abstract}

Keywords: air pollution; particulate; PM2.5; open market; pedestrian traffic

\section{Introduction}

Air quality in the world is a current concern for both developed and developing countries $(1,2,3,4)$. It is reported that 53 per 100,000 capita global deaths were attributable to ambient air pollution, $3,732,500$ deaths average $(5,6,7,8,9)$. The data observed show the impact on human health from pollutants such as particulate matter (PM10 and PM2.5), Ozone (O3), Nitrogen oxides (NOx) and Sulphur dioxide (SO2). It is reported that air pollution in 2012 caused the deaths of around 7 million people worldwide $(7,8,10)$. Air quality refers to the condition of the air within our surrounding that is free of gaseous impurities and pollutants such as smoke, dust and smog $(11,12,13)$. The good quality of air can be degraded by the day to day emissions from different air pollution sources especially in the marketplace $(13,14)$.

Pedestrian traffic in market places involves people moving to and fro by foot for different activities in the market, this causes air pollution, which is often neglected. Air pollution caused by pedestrian traffic is one of the major problems depleting the quality of air within market places and it is a pointer to its overall sustainability and user's well-being $(15,16)$. Most of our local markets are not well structured, most roads within the markets are also untarred, the to and fro movement of pedestrians, vehicles, truck-pushers etc. in the market contribute to the release of particulates/ dust. Nearly 30 to 40 percent of the population of a Yoruba town is engaged in trade and commerce $(17,18,19)$. Apart from the business done in shops and stores on the streets, most of the trading activities take place in town and village markets. Roadside vendors generally spend 8-10 hours on the margins of the road and are continuously exposed to the vehicular emissions as well as fugitive 
dust (20). Many market places, shops, business centres are close to roadsides thereby exposing these people to harmful pollutants which may have no serious effects now but in the long term could lead to respiratory diseases and possibly death. Some common air pollutants in marketplaces include; carbonmonoxide, nitrogendioxide, sulphurdioxide, hydrogensulphide, volatile organic compounds, ammonia, methane and total suspended particulate. The presence of these pollutants in the air depends on the nature of the activities within the market.

In recent times, studies of air pollution, especially in the urban environment, have focused largely on respirable dust, including seasonal variation and the threat poses to human health (Lazor et al, 2012). Respirable dust pollution which contributes to atmospheric heavy metal load is derived through natural and anthropogenic activities $(21,22)$. The respirable fraction is composed of the very fine dust which can reach the lower bronchioles and alveolar regions of the lung, this dust has been implicated to have the potential to carry a high loading of contaminated species such as heavy metals and organic pollutants. Few studies have reported annual mean levels of coarse and fine particles, collective evidence from short- and long-term air monitoring studies across urban Africa and demonstrate that pollution levels often exceed international guidelines (23). Particulate matter (PM) pollution is a serious issue of global concern. It has many negative impacts on humans, environment and atmospheric conditions including cloud formation, solar radiation, global warming, visibility and precipitation $(24,25)$. Nigeria is still far behind in cut-edge researches on air pollution compared to developed nations of the world. Few works have been done on PM determination and source apportionment in Nigeria $(26,27,28)$. These reported studies were based mainly on total suspended particles while few on coarse particles, PM10 and fine particles.

It has been estimated that a man can live weeks without food and five days without water, but only five minutes without air $(21,29)$. This implies that air is very essential for human existence. Various authors have researched particulate matter; using roads, vehicles and industrial areas as reference points $(9,21,30,31,32,33,34,35,36)$. Thereby giving increasing evidence to suggest that pollution from particulate which is one of the most common pollutants in market places, at levels hitherto considered "safe" is associated with an increased risk of morbidity and mortality (disease and death) from heart disease as well as lung disease. However, most of these researchers focused on industrial areas and traffic emission with little consideration to open market which is also one of the major areas of concern due to the various activities in the market which pollute the air and considering the number of pedestrians in the market, thereby endangering the public health, hence the necessity for this study.

\section{Materials and Methods}

\subsection{Study Area}

Bodija market in Ibadan, Oyo State, and a cosmopolitan city whose population continues to increase daily. The market is situated along the secretariat - U.I road, within the territory of Ibadan North Local Government, which is the most populated of the 11 local governments (see figure 1). The market is bordered in the North by Agbowo and Orogun, in the south by Bodija estate, while in the West and East are Sango and Bashorun/ Ashi respectively. The location of the market has a lot of advantages. From the viewpoint of proximity, the market is easily accessible to agriculturists, who come from Saki, Oyo, Ogbomoso and the Northern parts of Nigeria. The location is also suitable for easy distribution in and out of the city as it is served by varying network of roads.

10 sample points were taken along the roads and shops restricted to pedestrian activities to represent particulate generation points by pedestrians. These sample locations cover areas of dense to sparse vehicular movement, pedestrian activities, grinding stores, chemical trading, foods etc. These sample points were considered as a representative of the entire market environment and spectrum of activities. 
Table 1. Sampling sites characteristics including geographic co-ordinates

\begin{tabular}{clc}
\hline $\begin{array}{c}\text { Sample } \\
\text { Points }\end{array}$ & \multicolumn{1}{c}{ Characteristics } & Co-ordinates \\
\hline \multirow{2}{*}{ PPP1 } & Mainly Provision stores & $07.43583 \mathrm{~N}, 003.91402 \mathrm{E}$ \\
& & Alt: $226.8 \mathrm{~m}$ \\
PPP 2 & Fruits and other groceries & $07.43571 \mathrm{~N}, 003.91391 \mathrm{E}$ \\
& & Alt: 226.6 \\
PPP 3 & Vegetables and pepper & $07.43604 \mathrm{~N}, 003.91434$ \\
& & Alt: 224.5 \\
PPP 4 & Vegetables, pepper, meat & $07.43589 \mathrm{~N}, 003.91427$ \\
& & Alt: 225.2 \\
PPP 5 & Mainly yam sellers & $07.43595 \mathrm{~N}, 003.91418 \mathrm{E}$ \\
& & Alt: 224.2 \\
PPP 6 & Yam flour sellers and little grinding mill & $07.43592 \mathrm{~N}, 003.91421 \mathrm{E}$ \\
& & Alt: $228.1 \mathrm{~m}$ \\
PPP 7 & Grinding mill & $07.43551 \mathrm{~N}, 003.91354 \mathrm{E}$ \\
& & Alt: 221.8 \\
PPP 8 & Foodstuffs such as rice, beans, melons, garri, etc & $07.43616 \mathrm{~N}, 003.91314 \mathrm{E}$ \\
& & Alt: 216.9 \\
PPP 9 & Abattoir & $07.43457 \mathrm{~N}, 003.91183 \mathrm{E}$ \\
& & Alt: 231.5m \\
PPP 10 & Plastics and other household utensils & $07.43573 \mathrm{~N}, 003.91409 \mathrm{E}$ \\
\end{tabular}

Source: Authors fieldwork 2020.

\subsection{Sampling}

Thermo Scientific MIE pDR-1500 particulate meter was to measure the concentration of PM2.5 within the study area. PM2.5 was chosen out of other particle sizes because of its recorded health effect, being the most dangerous respirable particles, causing a different kind of lung diseases. The device used for monitoring is an easy to use equipment that provides fast and accurate measurement of particulate contamination in particles per cubic foot. The device was switched on and then calibrated. It was then placed on a stable platform to ensure the accuracy of the measurement. The measurement was recorded when the readings on the display screen were stable. Readings of PM2.5 was done at each sample point in the market in such a way that three readings were taken at every 2 minutes for 12 minutes in other to get the average readings for that minute to ensure accuracy. The monitoring was carried out in the morning and afternoon corresponding to peak market activities for our (4) weeks during the dry season and four (4) weeks during the wet season. 


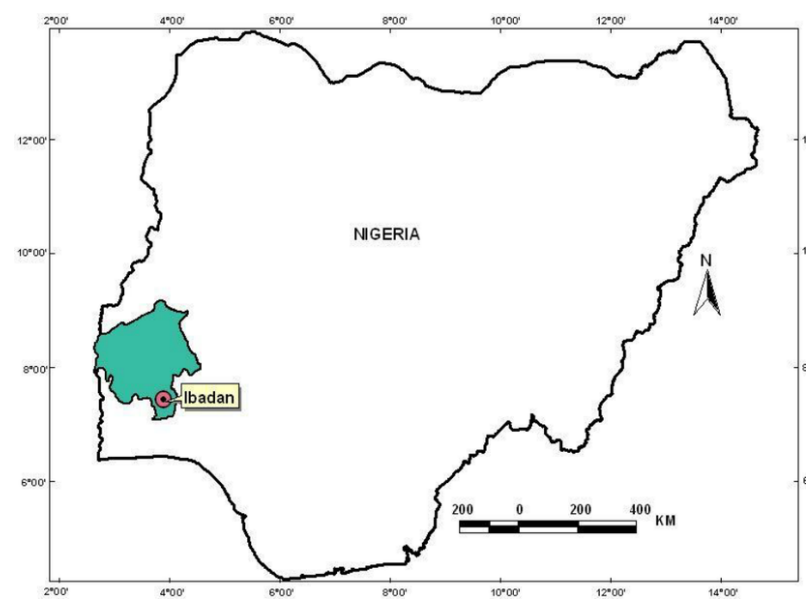

(a)

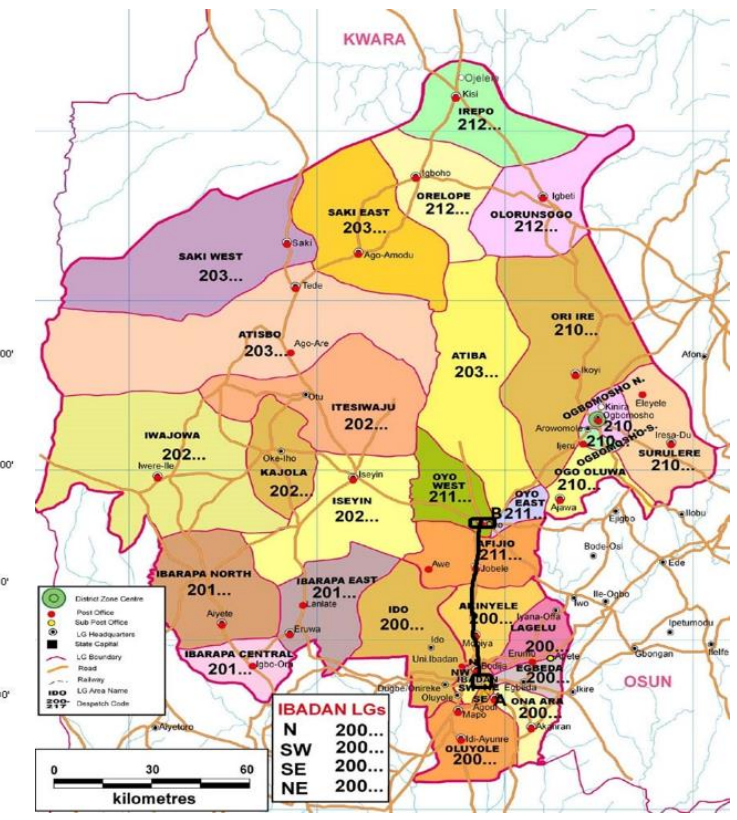

(b)

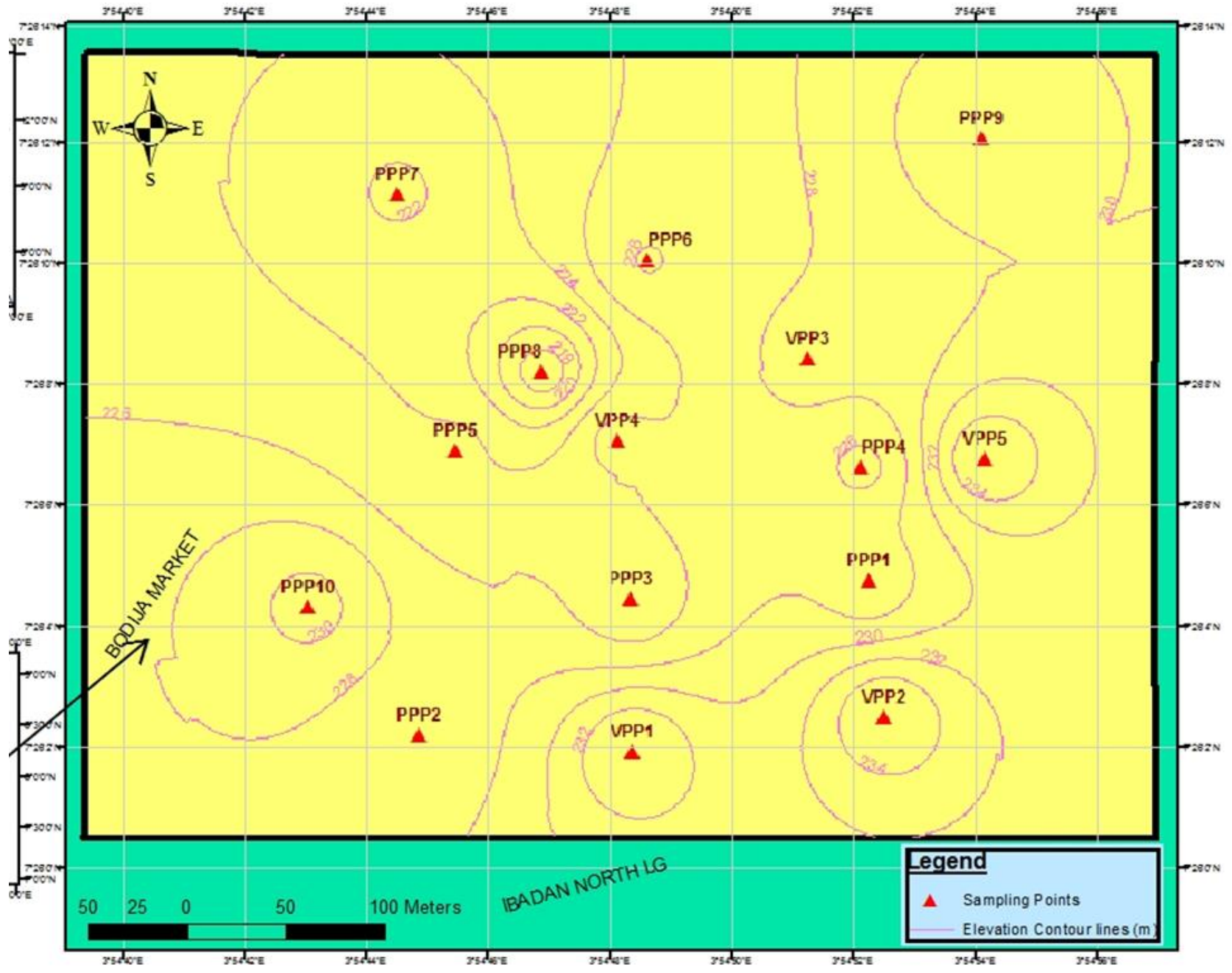

(c)

Figure 1. Map of the study area showing the sample points (a) Map of Nigeria showing Oyo State (Source: adapted from Google map); (b) Map showing the study area in Ibadan, Oyo State. (Source: adapted from Google map); (c) sample points at Bodija Market, Ibadan. Source: Authors fieldwork 


\section{Results}

Table 2. Average weekly morning PM2.5 readings from both vehicular and pedestrian traffic for the dry season.

\begin{tabular}{ccccc}
\hline Sample Points & \multicolumn{4}{c}{$\begin{array}{c}\text { Average weekly concentration of PM } \\
(\mu \mathbf{s} / \mathbf{m} \text { 3) }\end{array}$} \\
\cline { 2 - 4 } & \multicolumn{4}{c}{ MORNING SESSION } \\
\cline { 2 - 4 } & Week 1 & Week 2 & Week 3 & Week 4 4 \\
\cline { 2 - 4 } & 52.47 & 51.20 & 53.57 & 52.83 \\
PPP 1 & 54.48 & 56.18 & 57.87 & 57.30 \\
PPP 2 & 51.83 & 55.42 & 53.83 & 55.68 \\
PPP 3 & 49.62 & 59.78 & 55.48 & 58.37 \\
PPP 4 & 72.63 & 203.52 & 71.97 & 61.78 \\
PPP 5 & 163.68 & 72.58 & 181.02 & 177.62 \\
PPP 6 & 219.20 & 231.88 & 230.47 & 227.00 \\
PPP 7 & 190.73 & 167.28 & 155.83 & 141.47 \\
PPP 8 & 55.10 & 60.60 & 52.20 & 51.70 \\
PPP 9 & 52.63 & 54.50 & 50.03 & 47.90 \\
PPP 10 &
\end{tabular}

Source: Authors fieldwork 2020.

Table 3. Average weekly afternoon PM2.5 readings from both vehicular and pedestrian traffic for dry season

\begin{tabular}{ccccc}
\hline Sample Points & \multicolumn{4}{c}{$\begin{array}{c}\text { Average weekly concentration of PM } \\
(\boldsymbol{\mu} \mathbf{2 . 5} \text { /m3) }\end{array}$} \\
\cline { 2 - 5 } & \multicolumn{4}{c}{ AFTERNOON dry season } \\
\cline { 2 - 5 } & Week 1 & \multicolumn{4}{c}{ Week 2 } & Week 3 & Week 4 \\
\cline { 2 - 4 } & 78.73 & 75.10 & 72.83 & 77.20 \\
PPP 1 & 74.42 & 74.85 & 77.23 & 73.10 \\
PPP 2 & 65.17 & 71.17 & 71.95 & 72.80 \\
PPP 3 & 75.52 & 77.65 & 71.83 & 71.48 \\
PPP 4 & 618.35 & 655.43 & 632.80 & 563.67 \\
PPP 5 & 1645.00 & 1806.33 & 1794.83 & 1779.93 \\
PPP 6 & 1539.67 & 1751.83 & 1704.23 & 1411.40 \\
PPP 7 & 465.95 & 527.12 & 569.55 & 537.85 \\
PPP 8 & 99.267 & 88.20 & 78.77 & 75.40 \\
PPP 9 & 110.25 & 87.62 & 68.82 & 73.15 \\
PPP 10 & &
\end{tabular}

Source: Authors fieldwork 2020. 
Table 4. Average weekly morning PM2.5 readings from both vehicular and pedestrian traffic for the wet season

\begin{tabular}{ccccc}
\hline Sample Points & \multicolumn{4}{c}{$\begin{array}{c}\text { Average weekly concentration of PM2.5 for dry season } \\
(\mu \mathrm{g} / \mathrm{m} 3)\end{array}$} \\
\cline { 2 - 5 } & \multicolumn{4}{c}{ MORNING SESSION } \\
\cline { 2 - 5 } & Week 1 & \multicolumn{3}{c}{ Wedestrians } \\
\cline { 2 - 4 } & 18.70 & 13.42 & 12.45 & 11.58 \\
\hline PPP 1 & 17.68 & 13.07 & 11.83 & 12.28 \\
PPP 2 & 15.33 & 15.27 & 12.42 & 12.63 \\
PPP 3 & 14.35 & 13.73 & 13.25 & 10.30 \\
PPP 4 & 24.03 & 20.18 & 18.85 & 13.30 \\
PPP 5 & 22.20 & 20.23 & 20.28 & 15.50 \\
PPP 6 & 31.18 & 27.77 & 27.57 & 24.48 \\
PPP 7 & 28.63 & 22.93 & 21.32 & 17.97 \\
PPP 8 & 22.60 & 18.92 & 17.43 & 14.47 \\
PPP 9 & 18.98 & 16.23 & 12.62 & 10.97 \\
PPP 10 & &
\end{tabular}

Source: Authors fieldwork 2020.

Table 5. Average weekly afternoon PM2.5 readings from both vehicular and pedestrian traffic for the wet season

\begin{tabular}{ccccc}
\hline Sample Points & \multicolumn{4}{c}{$\begin{array}{c}\text { Average weekly concentration of PM } \\
(\boldsymbol{\mu} \mathbf{g} / \mathbf{m} \text { 3) }\end{array}$} \\
\cline { 2 - 5 } & \multicolumn{4}{c}{ AFTERNOON dry season } \\
\cline { 2 - 5 } & Week 1 & \multicolumn{4}{c}{ Week 2 } & Week 3 & Week 4 \\
\cline { 2 - 5 } & 25.68 & 23.65 & 23.70 & 20.33 \\
PPP 1 & 24.27 & 23.63 & 20.37 & 18.85 \\
PPP 2 & 26.90 & 27.67 & 23.57 & 22.30 \\
PPP 3 & 23.18 & 27.20 & 24.62 & 18.28 \\
PPP 4 & 57.87 & 41.67 & 35.55 & 26.93 \\
PPP 5 & 61.05 & 44.68 & 37.67 & 21.38 \\
PPP 6 & 750.57 & 589.03 & 567.63 & 222.45 \\
PPP 7 & 113.85 & 94.53 & 102.53 & 51.37 \\
PPP 8 & 56.47 & 32.13 & 28.17 & 22.52 \\
PPP 9 & 29.42 & 22.83 & 18.50 & 17.17 \\
PPP 10 & &
\end{tabular}

Source: Authors fieldwork 2020.

\section{Discussion}

From tables 2 and 3, it could be deduced that the concentration of PM2.5 caused by pedestrian activities is higher than the measured control from a closed market. The concentration varied from $52.47 \mu \mathrm{g} / \mathrm{m} 3-219.20 \mu \mathrm{g} / \mathrm{m} 3$ in the first week of morning monitoring in the dry season, $51.20 \mu \mathrm{g} / \mathrm{m} 3-$ $231.88 \mu \mathrm{g} / \mathrm{m} 3$ for the second week of monitoring, $50.03 \mu \mathrm{g} / \mathrm{m} 3-230.47 \mu \mathrm{g} / \mathrm{m} 3$ and $47.90 \mu \mathrm{g} / \mathrm{m} 3-227.0$ $\mu \mathrm{g} / \mathrm{m} 3$ for third and fourth week morning monitoring respectively while the concentration varies in the afternoon from $65.17 \mu \mathrm{g} / \mathrm{m} 3-1539.67 \mu \mathrm{g} / \mathrm{m} 3,71.17 \mu \mathrm{g} / \mathrm{m} 3-1806.33 \mu \mathrm{g} / \mathrm{m} 3,71.83 \mu \mathrm{g} / \mathrm{m} 3-1794.83$ $\mu \mathrm{g} / \mathrm{m} 3,71.48 \mu \mathrm{g} / \mathrm{m} 3-1779.93 \mu \mathrm{g} / \mathrm{m} 3$ for the first, second, third and fourth week respectively. World Health Organization (WHO) recommends $25 \mu \mathrm{g} / \mathrm{m} 3$ while the National Ambient Air Quality 
Standard (NAAQS) recommends $35 \mu \mathrm{g} / \mathrm{m} 3$ as the maximum permissible limit that ensures $95 \%$ safety from lung diseases. However, none of these sample points within the market meets up with the standards either in the morning or afternoon. Figures 2 and 3 gives the trend of PM2.5 pollution by pedestrian traffic within the study area for the four weeks monitoring as compared with the control for the study, WHO, and NAAQS standards. It is evident from the graph that the concentration of PM2.5 during the dry season is very high against the standards with an elevated concentration in the afternoon. The elevated concentration of PM2.5 at the study area is due to the activities of the pedestrians within the market which causes the release of particulate into the atmosphere. Activities such as grinding of yam flour (Elubo), a crowd walking up and down on untarred roads including carriers, hawkers and buyers within the market, the release of particulates by the foodstuff sellers especially when cleaning beans, garri etc increases the concentration of particulates into the atmosphere.

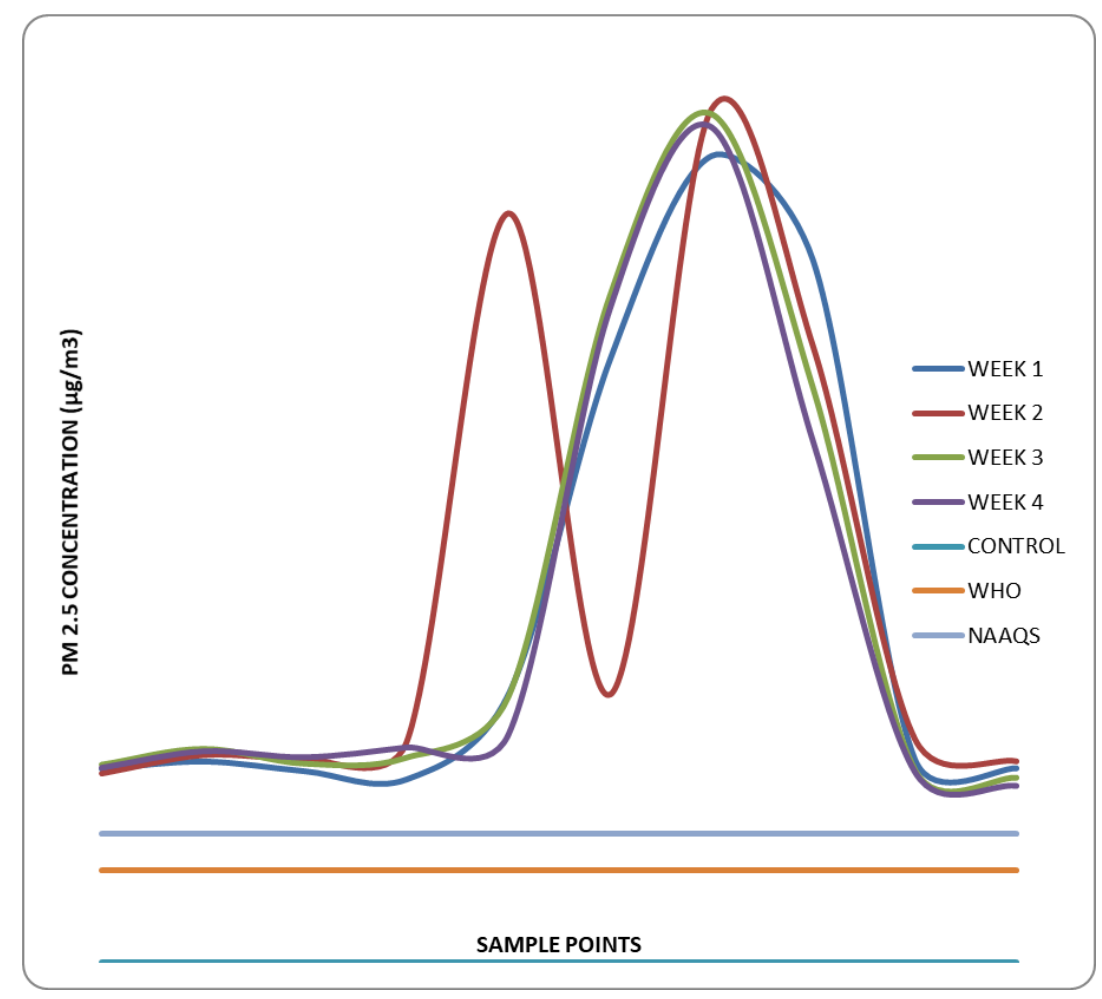

Figure 2. The trend of PM2.5 pollutions by pedestrians in the morning during the dry season

A high concentration of particulates in the afternoon is due to an increase in market activities in the afternoon than in the morning. Also, the season affects the increase in the concentration of PM2.5 in the air as there is no enough moisture content in the air to absorb the particulates released into the atmosphere by these pedestrians. PM2.5 which is highly respirable of all the particulate matter and can get deep into the lung and kidney, thereby causing a lung infection. However most of the market dwellers are negligence of its impact on their health, hence they do not care to use protective. It was reported by Petrova et.al 2015 in the review of air pollution in African cities that despite the health risk air pollution presents, air quality programs, particularly in Sub-Sahara Africa, have been stalled or discontinued in recent years, hence the increase in depletion of air quality and less awareness. 


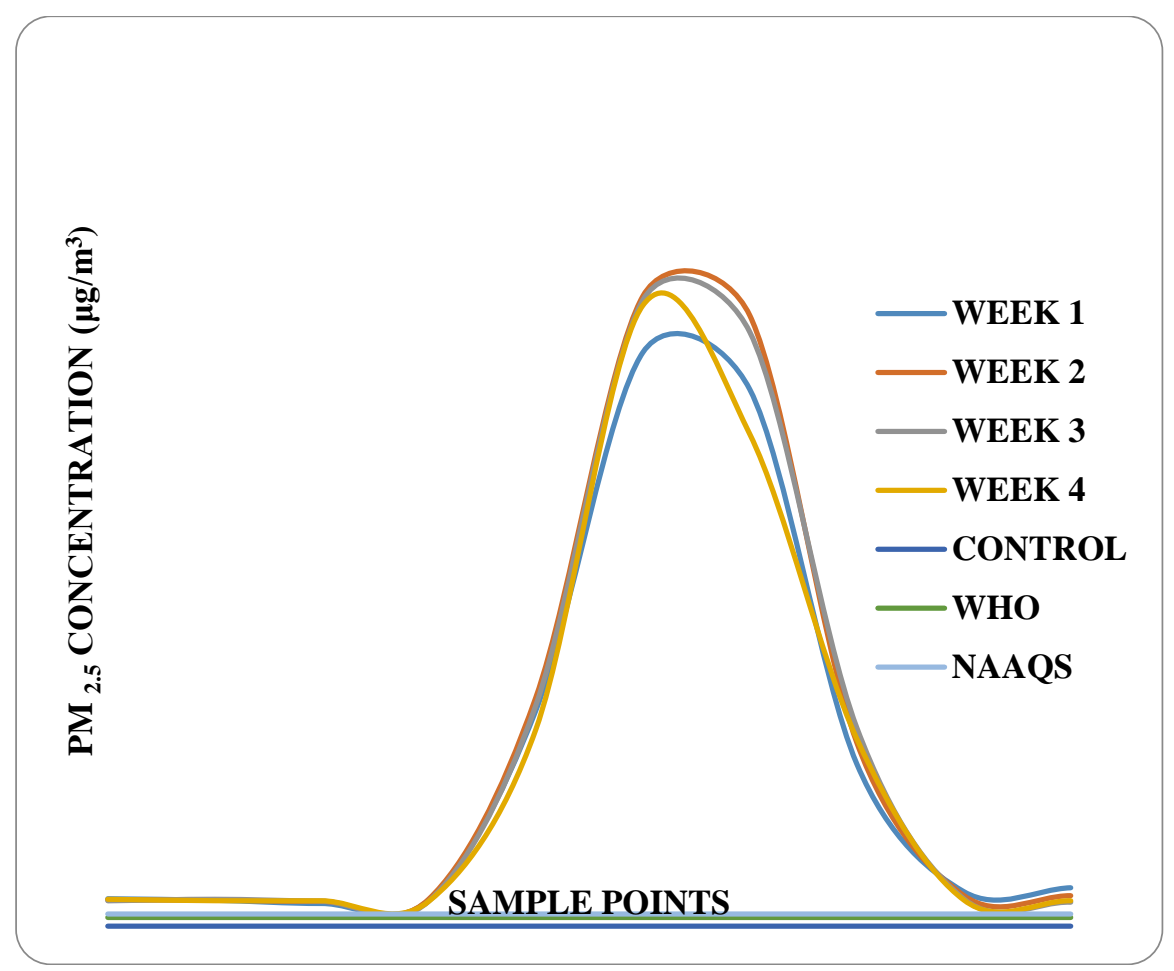

Figure 3. The trend of PM2.5 pollutions by pedestrians in the afternoon during the dry season

The mean concentration of PM2.5 by pedestrian traffic during wet season compared with standard as presented in Tables 4 and 5 above shows that some of the locations have a concentration within WHO and NAAQS standard in the morning ranging from $14.35 \mu \mathrm{g} / \mathrm{m} 3-31.18 \mu \mathrm{g} / \mathrm{m} 3,13.07$ $\mu \mathrm{g} / \mathrm{m} 3-27.77 \mu \mathrm{g} / \mathrm{m} 3,11.83 \mu \mathrm{g} / \mathrm{m} 3-27.52 \mu \mathrm{g} / \mathrm{m} 3,10.30 \mu \mathrm{g} / \mathrm{m} 3-24.48 \mu \mathrm{g} / \mathrm{m} 3$ for the first week, second, third and fourth week respectively while the concentration slightly increases in the afternoon ranging from $24.27 \mu \mathrm{g} / \mathrm{m} 3-750.57 \mu \mathrm{g} / \mathrm{m} 3,22.83 \mu \mathrm{g} / \mathrm{m} 3-589.03 \mu \mathrm{g} / \mathrm{m} 3,18.50 \mu \mathrm{g} / \mathrm{m} 3-567.63 \mu \mathrm{g} / \mathrm{m} 3,17.17$ $\mu \mathrm{g} / \mathrm{m} 3-222.45 \mu \mathrm{g} / \mathrm{m} 3$ for the first, second, third, and fourth week respectively during afternoon monitoring for the wet season. Some of the sample points do not fall within WHO and NAAQS, some falls within the WHO standard but above NAAQS standard, while the control experiment falls within both standard. PPP7 has elevated value ranging from $222.45 \mu \mathrm{g} / \mathrm{m} 3-750.57 \mu \mathrm{g} / \mathrm{m} 3$. The concentration of PM2.5 in wet season ranges from $10.30 \mu \mathrm{g} / \mathrm{m} 3-32.18 \mu \mathrm{g} / \mathrm{m} 3$ in the morning and $17.17 \mu \mathrm{g} / \mathrm{m} 3-$ $750.57 \mu \mathrm{g} / \mathrm{m} 3$ in the afternoon. Figures 4 and 5 below gives the trend of particulate pollution by pedestrian traffic during the wet season for morning and afternoon periods, it is evident from the graph that the reduction in the concentration of PM2.5 is inward wet season, the first week of monitoring has the highest concentration being the inception of raining season i.e onset of the raining season while the concentration reduces towards the wet season. The reduction in the level of PM2.5 during this period is because there is enough moisture in the atmosphere to absorb these particulates. Also, the untarred floor will have high moisture content hence, little or no particulate will be generated by the to and the fro movement of the market dwellers. However, the foodstuff sellers and millers are at high risk of inhaling PM2.5 (respirable dust) during this period while grinding, dusting beans, garri, melon, etc without using protective at least a nose mask. Aybek and Selcuket 2007, reported that respirable dust is a useful indicator of the level and distributor of heavy metals contamination in the atmosphere which may affect air quality with its deleterious environmental consequences including harm to human life, this shows how dangerous PM2.5 could be which is at high concentration in the market. 


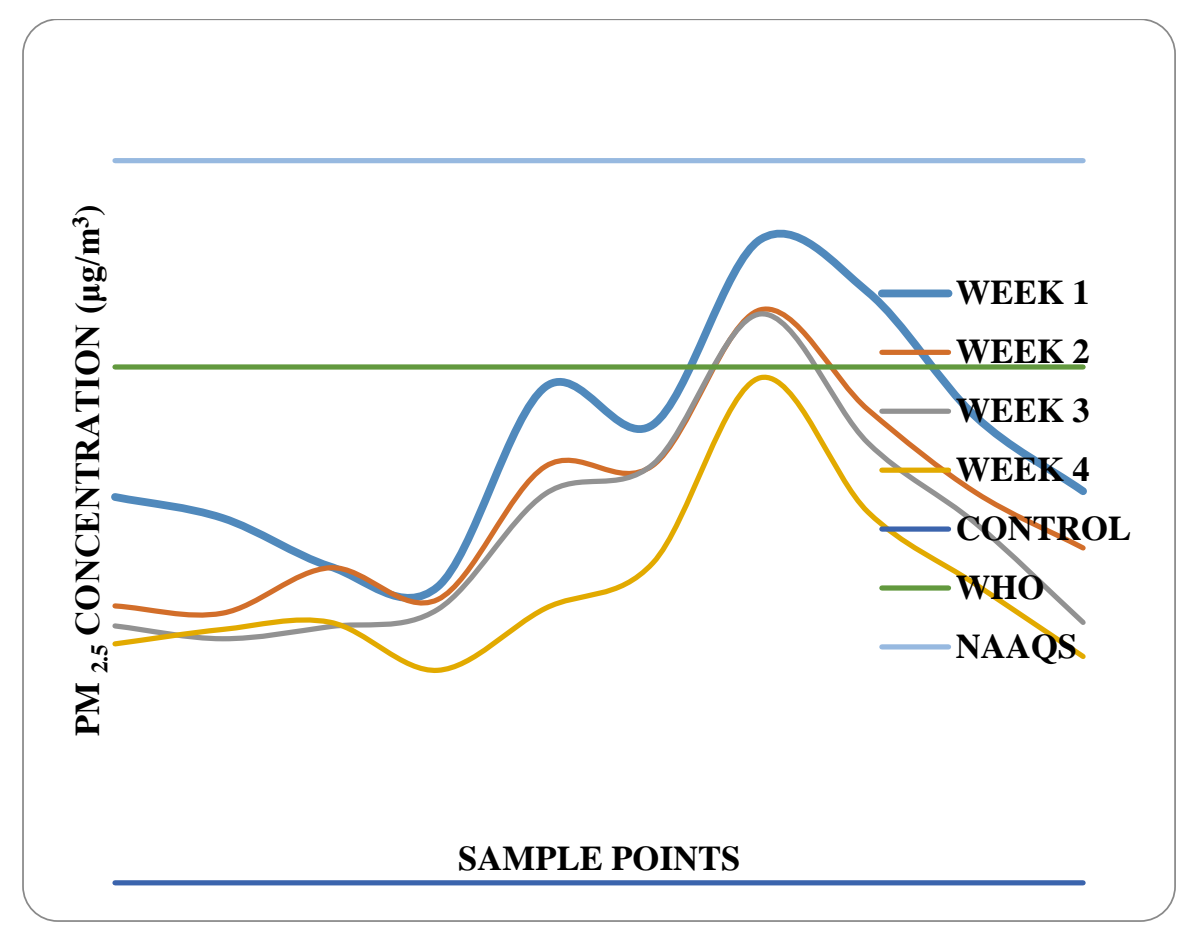

Figure 4. The trend of PM2.5 pollutions by pedestrians in the morning during the wet season

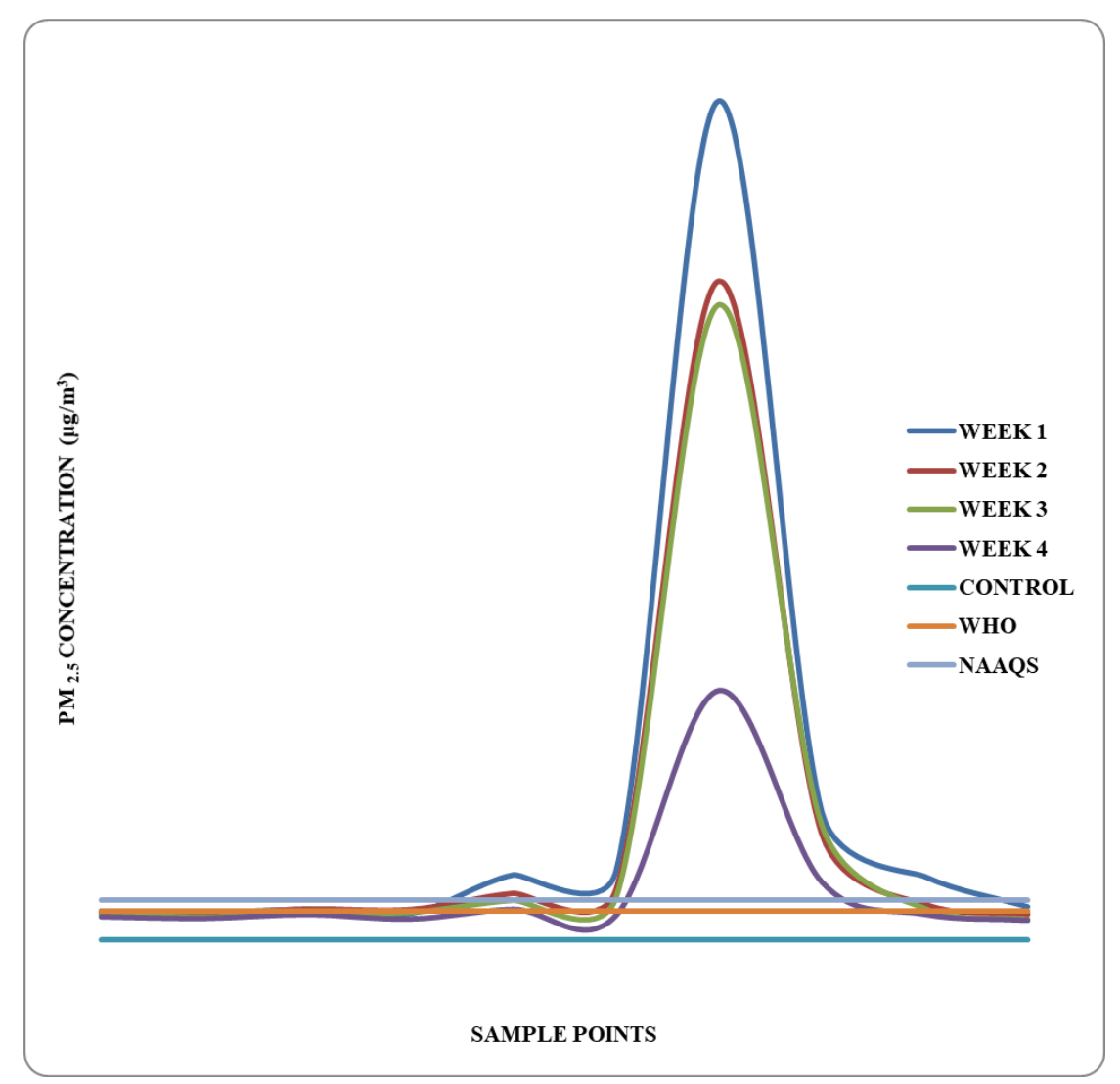

Figure 5. The trend of PM2.5 pollutions by pedestrians in the afternoon during the wet season

The experimental data reveal that the concentration of PM2.5 is higher in the dry season than a wet season at different sections of the market, this complies with the research made by Gobo et al after assessing the air quality and noise around Okrika Communities, Rivers State. 


\section{Conclusions and Recommendations}

In the present study, an extensive evaluation of air pollution from pedestrian traffic in an open market was conducted using Bodija market as a case study. Air quality monitoring device (PM meter) was used to monitor the concentration of PM2.5 (which is the most dangerous size of particulate) from pedestrian traffic during the dry and wet season. The assessment of PM2.5 concentration caused by pedestrian traffic shows exceedances of the standards stated by WHO and NAAQS during dry season whereas the concentration falls within the standard for the wet season except for some areas of the market especially grinding mill section which violated the $25 \mu \mathrm{g} / \mathrm{m} 3$ by WHO and NAAQS 35 $\mu \mathrm{g} / \mathrm{m} 3$ irrespective of the season. With these elevated concentrations of PM2.5 in the market, it is evident from the survey that air pollution affects the health of pedestrians in the market. Most of them experience sneezing, irritation of eyes, nose and throat, headache etc which are the most common symptoms related to air pollution. Prolonged exposure without a remedy may affect their internal organ especially those at the grinding mill section and foodstuff sellers. Hence, attention is needed in this sector of the economy as it is an important sector that cannot be overlooked.

\section{References}

1. Quansah, R.; Semple, S.; Ochieng, C.A.; Juvekar, S.; Armah, F.A.; Luginaah. I.; Emina, J. Effectiveness of interventions to reduce household air pollution and/or improve health in homes using solid fuel in lowand-middle-income countries: A systematic review and meta-analysis. Environ Int. 2017 Jun; 103, 73-90.

2. Ezzati, M.; Utzinger, J.; Cairncross, S.; Cohen, A.J.; Singer, B.H. Environmental risks in the developing world: exposure indicators for evaluating interventions, programmes, and policies. J Epidemiol Community Health. 2005 Jan; 59(1), 15-22.

3. Mannucci, P.M.; Harari, S.; Martinelli, I.; Franchini, M. Effects on the health of air pollution: A narrative review. Intern. Emerg. Med. 2015, 10, 657-662. doi: 10.1007/s11739-015-1276-7.

4. Tuomisto, J.T.; Andrew, W.; John, S.E.; Marko, T. “Uncertainty in Mortality Response to Airborne Fine Particulate Matter: Combining European Air Pollution Experts." Reliability Engineering \& System Safety 2008, 93 (5). Elsevier: 732-44.

5. Burroughs, P.M.S.; Rollins, A. Environmental exposures and cardiovascular disease: A challenge for health and development in low- and middle-income countries. Cardiol. Clin. 2017, 35,71-86. doi: 10.1016/j.ccl.2016.09.001.

6. World Health Organization (WHO). Air Quality Guidelines for Europe. WHO Regional Publications, European Series No. 91, WHO Regional Office for Europe, Copenhagen, 2000.

7. WHO. "Burden of Disease from Ambient Air Pollution for 2012." (2014). (http://www.who.int/phe/health_topics/outdoorair/databases/AAP_BoD_results_March2014.pdf).

8. WHO. "WHO 7 Million Premature Deaths Annually Linked to Air Pollution." 2014, March. World Health Organization. (http://www.who.int/mediacentre/news/releases/2014/air-pollution/en/)

World Health Organization (WHO), 2005. Air Quality Guidelines for Particulate Matter, Ozone, Nitrogen dioxide and Sulphur dioxide. Global update summary of risk assessment WHO/SDE/PHE/OEH/06.02. Available at http://www.euro.who.int/Document/E87950.pdf.

9. Zagha, O.; Nwaogazie, I. L.; Roadside Air Pollution Assessment in Port-Harcourt, Nigeria. Standard Scientific Research and Essays 2012, 3(3): 066-074(ISSN: 2310-7502) http://www.standresjournals.org/journals/SSRE.

10. Piqueras, P.; Vizenor, A. The rapidly growing death toll attributed to air pollution: a global responsibility. Policy Brief for GSDR 2016, pp. 1-4.

11. Tilt, B. China's air pollution crisis: Science and policy perspectives. Environmental Science \& Policy 2019, 92, 275.

12. Plaia, A.; Ruggieri, M.; Air quality indices: a review. Rev Environ Sci Bio 2011, 10,165-79.

13. Manisalidis, I.; Stavropoulou, E.; Stavropoulos, A.; Bezirtzoglou, E. Environmental and Health Impacts of Air Pollution: A Review. Frontiers in Public Health 2020, 8, Article14 DOI=10.3389/fpubh.2020.00014 ISSN=2296-2565

14. Schwela, D. Air pollution and health in urban areas. Rev Environ Health 2000. Jan-Jun;15(1-2):13-42. doi: 10.1515/reveh.2000.15.1-2.13. 
15. Lelieveld, J., Evans, J.S.; Fnais, M.; Giannadaki, D.; Pozzer, A. The contribution of outdoor air pollution sources to premature mortality on a global scale. Nature. 2015; 525:367-371. doi: 10.1038/nature15371.

16. Liu, Y.; Lee, K.; Perez-Padilla, R.; Hudson, N.L.; Mannino, D.M. Outdoor and indoor air pollution and COPD-related diseases in high- and low-income countries. Int. J. Tuberc. Lung. Dis. 2008; 12,115-127.

17. Balogun, F. A. Management of Traditional Markets in Ibadan, Nigeria: A Focus On Oja'ba and Oje Markets. 2011.

18. Filani, M.O. Ibadan Region, Rex Charles Publication, Ibadan 1994; p.169.

19. Odeyale, T.O.; Omole, F.K.; Sodagar, B.; Temple, N.; O'Coill, C. “Traditional Food markets, Power Relations and Waste Management: A Qualitative Study. In V. Popov, H. Itoh and C.A. Brebbia (Eds.) Waste Management and the Environment VI, WIT Transaction on Ecology and the Environment 2012, 163, pp. 37-47. (ISSN 1743-3541).

20. Mani, P.A.; Swamy, A.V.; Hema, K.R. Studies on the Transport Related Pollutants in the Ambient Atmosphere and their Health Impacts on the Roadside Vendors of the Indian city", Eur. Chem. Bull. 2013. 2(1), 28-37.

21. Mafuyai, G.M.; Eneji, I.S.; Sha'Ato, R. Concentration of Heavy Metals in Respirable Dust in Jos Metropolitan Area, Nigeria. Open Journal of Air Pollution 2014, 3, 1019.http://dx.doi.org/10.4236/ojap.2014.31002.

22. Shah, J.; Nagpa, J.T.; Brnadon, C. Urban air Quality Management Strategy in Asia-Guide Book. The World Bank, USA, 2006, 17-21.

23. Petkova, E.P.; Darby, W.; Jack, N.; Volavka-Close, H.; Patrick, L. K. Particulate matter pollution in African cities. Air Quality Atmospheric Health 2013, 6, 603-614 DOI 10.1007/s11869-013-0199-6.

24. Taiwo, A.M.; Beddows, D.C.S.; Shi, Z.; Harrison, R.M. Mass and number size distributions of particulate matter components: Comparison of an industrial site and an urban background site. Sci Tot Environ 2014. 475, 29-38.

25. Pope, C.A.; Dockery, D.W. Health Effects of Fine Particulate Air Pollution: Lines that Connect. Journal of the Air $\mathcal{E}$ Waste Management Association 2006, 56, 709-742. http://dx.doi.org/10.1080/10473289.2006.10464485.

26. Owoade, O. K.; Fawole, O.G.; Olise, F.S.; Ogundele, L.T.; Olaniyi, H.B.; Almeida, M.S.; Ho M.D.; Hopke P.K. Characterization and source identification of airborne particulate loadings at receptor site-classes of Lagos mega-city, Nigeria. J Air \& Waste Managt Assoc 2013, 63, 1026-1029.

27. Efe, S.I.; Efe, A.T. Spatial distribution of particulate matter (PM10) in Warri metropolis, Nigeria. The Environ 2008, 28, 385-394.

28. Koku, C.A.; Osuntogun, B.A. Environmental impacts of road transportation in the Southwestern States of Nigeria. J Appl Sci 2007, 7 (16), 2536-2360.

29. Rao, M.N.; Rao, H.V.N. Air Pollution. Data McGraw-Hill Publishing Company Ltd., New Delhi, 1989, pp. $10-25$.

30. Nwankwoala, H.O.; Obioha, S.C.; Preliminary Assessment of Air and Sound Quality in Ariaria Market, Aba, Southeastern Nigeria. Journal of Engineering and Technology Research 2014, 2(4), 18-26 (http://www.scientiaresearchlibrary.com/arhcive.php)

31. Taiwo, A.M.; Arowolo, T.A.; Abdullahi, K.L.; Taiwo O.T. Particulate Matter Pollution in Nigeria: A Review. Proceedings of The 14th International Conference On Environmental Science and Technology Rhodes, Greece, 2015,3-5.

32. Kim, K-H; Ehsanul, K.; Shamin, K. A review on the human health impact of airborne particulate matter. Environment International 2015, 74, 136-143. http://dx.doi.org/10.1016/j.envint.2014.10.005

33. Offor, I.F.; Gilbert, U.; Adie, G.; REE, A. Review of Particulate Matter and Elemental Composition of Aerosols at Selected Locations in Nigeria from 1985-2015. Journal of Health $\mathcal{E}$ Pollution 2016, 6(10).

34. Aybek, A.; Selcuk, A. Dust Exposures in Tractor and Combine Operations in Eastern Mediterranean, Turkey. Journal of Environmental Biology 2007, 28, 717-722. http://www.jeb.co.in/

35. Gobo, A.E.; Ideriah, T.J.K.; Francis, T. E.; Stanley, H.O. Assessment of Air Quality and Noise around Okrika Communities, Rivers State, Nigeria. Journal of Applied Science and Environmental Management 2012, 16 (1), 75 - 83. Full-text Available Online atwww.ajol.infoandwww.bioline.org.br/ja

36. Lazor, P.; Tomas, J.; Toth, T.; Toth, J.; Ceryova, S. Monitoring of Air Pollution and Atmospheric Deposition of Heavy Metals by Analysis of Honey. Journal of Microbiology, Biotechnology and Food Sciences, 1, 2012, 522533. 